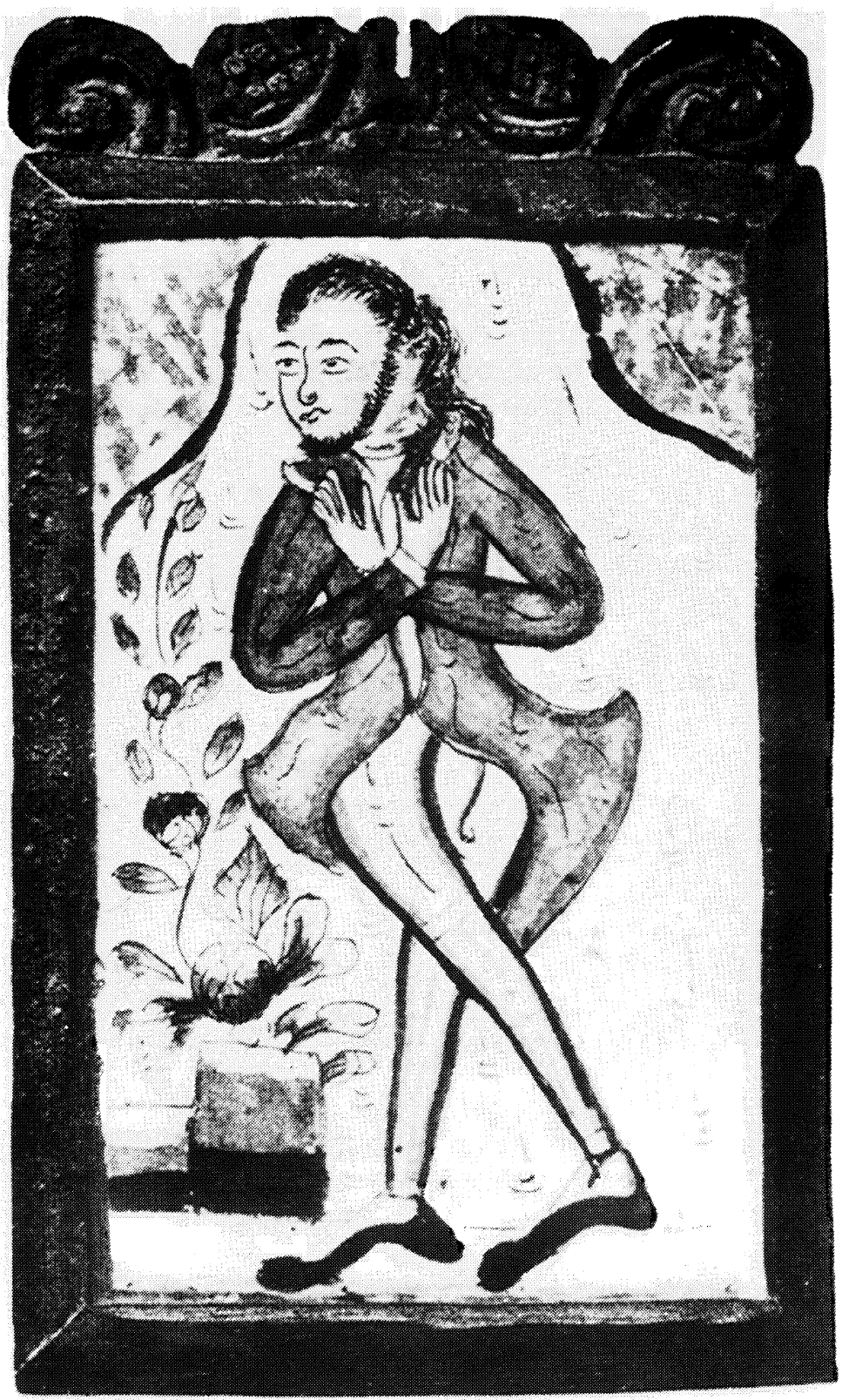

PLATE I: Mads Lange (Balinese painting) 


\title{
THE MADS LANGE CONNECTION \\ A DANISH TRADER ON BALI IN THE MIDDLE OF THE NINETEENTH CENTURY: BROKER AND BUFFER ${ }^{1}$
}

\author{
Henk Schulte Nordholt
}

\section{Introduction}

During the nineteenth century the Dutch colonial state in the Indonesian archipelago gradually came into being. After the Diponegoro Revolt, or Java War (18251830 ), and the introduction of the so-called "Culture System" in the 1830s, Dutch colonial government was established in Java. The "Outer Islands," however, except for limited regions, were politically still independent, and it was not until the beginning of the twentieth century that nearly the whole archipelago came under colonial rule.

Dutch policy towards these "Outer Islands" was ambiguous during the nineteenth century. On the one hand the official policy was one of noninterference, because government attention had to be paid primarily to Java; but, on the other hand, several large-scale military expeditions were launched against areas outside Java, for instance, Bone (1824, 1858-60), West Sumatra (the Padri war, 1830-37), Banjarmasin (1859-63), and Bali $(1846,1848$, and 1849). Whereas for most of the nineteenth century Dutch policy towards the "Outer Islands" can be characterized as "reluctant imperialism," during the latter decades of that century a stronger expansion of the colonial state began to take place; but it was not until the beginning of the twentieth century that the Dutch colonial state assumed its final form.

During the phase of "reluctant imperialism" there was, outside Java, substantial scope for activity by foreign intermediaries between the growing colonial state and the indigenous rulers. In some instances this space was filled by Western adventurers such as, for instance, Raja James Brooke in Sarawak in the 1840s and Erskine Murray in Kutai. Raja Brooke succeeded in establishing a kind of private

1. This article is a revised version of a paper presented at the third Dutch-Indonesian Historical Conference, held at De Lage Vuursche, Holland, June 23-27, 1980. I am grateful to Professor Heather Sutherland for her comments on an earlier version. The research was conducted during the preparation of my MA thesis on patterns of political dynamics in Balinese history, "Macht, mensen en middelen: patronen van dynamiek in de Balische politiek $\pm 1700-1840$," submitted to the faculty of history of the Free University in Amsterdam, 1980. My current Ph.D. research is on "Balinese royal power and colonial government, 1840-1940." Plate $I$ is from F. H. van Naerssen, Th. G. Th. Pigeaud and P. Voorhoeve, Catalogue of Indonesian Manuscripts, pt. 2 (Copenhagen: Royal Library of Copenhagen, 1977), p. 34, containing Mads Lange's Balinese letters. The Royal Library of Copenhagen kindly permitted me to use this drawing. Plate II is from W. R. van Hoëvell, Reis over Java, Madura en Bali in het midden van 1847, 2 (Amsterdam: van Kampen, 1851), opposite p. 214. 
state, but Murray failed. ${ }^{2}$ Kalimantan was not the only area which witnessed attempts by European merchant-adventurers to create their own intermediate sphere of influence; they were also active on the islands of Bali and Lombok.

One of these adventurers was Mads Johansen Lange from Denmark, who lived on Lombok from 1834 until 1839, and from then, until his death in 1856, on the southern peninsula of Bali, near the village of Kuta. His residence on Bali coincided with Dutch attempts to gain control over the island, and Mads Lange played an important role in this early colonial expansion. In this article, I will try to analyze Lange's role as a link between the world of South Bali and the outside, and will illustrate several different, but interrelated aspects to the function he fulfilled.

In the first place Mads Lange was a commercial broker. The factory he established near Kuta formed a vital hinge between inter-Asiatic trade and the inland Balinese economy, which both sides needed to maintain contact with each other. At the same time Lange used both parties for his own profit.

Second, Lange was used as a channel of information by the Dutch and by the South Balinese rajas. The information he provided was of vital importance to the very different political purposes of each side. Moreover, the Lange factory became a kind of neutral meeting ground for the Dutch and the South Balinese.

In the third place, Lange was a buffer, and acted as a mediator whose prime purpose was to reconcile conflicting parties. He was less a manipulator, trying to gain personal profit from his mediating position, than a reconciler whose aim was to solve conflicts and to keep opposing parties apart. In this sense Lange acted primarily as a buffer between Dutch colonial intersts and South Balinese politics.

This three-part combination constituted the Mads Lange connection. Lange lived in a kind of no-man's-land between the Balinese system and outside. He found his role and meaning in this space. He, himself, however, was not solely responsible for creating the space, for the Danish trader fitted into an existing structure which determined the limits of his possible activity.

Questions I will try to answer in the following pages are: what structural conditions made this connection work? How did it work? Who made use of it and why? And what, after all, was Lange's own personal profit?

\section{The Balinese Background}

Before considering the life and times of Mads Lange on Bali, we need to know more about the historical background of the contacts between Bali and the outside world, and the space between them in which foreigners could maneuver.

\section{Isolation and Contact}

Ever since the fall of the kingdom of Majapahit in the fifteenth century, a Hindu-oriented court tradition continued on Bali. From then on Gelgel and subsequently Klungkung, in the southern rice-growing area of the island, were the centers of Balinese politics. There the Dewa Agung, the "king" who was more or less recognized as the highest authority, had his residence. Around him and other rajas and lesser lords there was a power structure, reaching from the center to

2. On Murray, see B. R. Pearn, "Erskine Murray's Fatal Adventure in Borneo, 1843-44," Indonesia, 7 (April 1969), pp. 21-32. 
the outskirts of the island, in which feuds were as frequent as professions of loyalty towards the center.

A common religious and political identity was preserved at the Balinese courts, based on the idea that the island formed the last stronghold of a glorious HinduJavanese royal tradition. Its preservation involved a deliberate political isolation vis-à-vis the outside world, because of the awareness that "Java," whether Mataram with its flavor of Islam, or the VOC, was a serious threat to that carefully guarded Hindu-Javanese tradition. This political isolation, however, was not so much based on a coherent policy of the Balinese rajas as on a kind of "cultural consensus" that the Balinese negara formed a world of its own in which foreign influences were not admitted. ${ }^{3}$ Apart from minor interventions in East Java, in an effort to protect the buffer status of Blambangan, and a gradual expansion towards Lombok, the Balinese rajas were reluctant to get involved in large-scale adventures which might endanger their autonomy. The relative isolation that resulted continued until at least the middle of the nineteenth century.

There was, however, a paradox, in that, at the same time, trade contacts between Bali and the outside world increased enormously from the seventeenth century on. The export of thousands of male and female slaves, mainly to Java, between 1620 and 1830 made Bali an important place on the commercial map of the archipelago. ${ }^{4}$ The exact nature and organization of the Balinese slave trade in the seventeenth and eighteenth centuries remain unclear, but from preliminary evidence it appears that at the end of the eighteenth century 1,000 to 2,000 slaves were exported from Bali every year. At that time, some reports indicate that Balinese constituted the largest element of Batavia's population. ${ }^{5}$ Although there are some indications that, from time to time, foreign traders (mostly Chinese and Buginese, but also a few Europeans) settled near the main harbors of the island and served as intermediaries, most of the slave trade was probably a matter of direct transactions between slave traders from outside and the local elite. ${ }^{6}$

3. On the "classical" Balinese state [negara], see Clifford Geertz, Negara, the Theatre State in Nineteenth Century Bali (Princeton: Princeton University Press, 1980).

4. In Java, many former Balinese slaves became mercenary soldiers. See Ann Kumar, Surapati, Man and Legend (Leiden: Brill, 1975). Most of the female slaves were bought by Chinese; see, for instance, C. Lekkerkerker, "Bali 1800-14," Bijdragen voor de Taal-, Land- en Volkenkunde [hereafter $B K I$ ], 82 (1926), pp. 315-38, especially pp. 328-29.

5. See report $F$. Rothenbuyler \pm 1815 , Koninklijk Instituut voor Taal-, Land- en Volkenkunde [hereafter KITLV], Leiden, $\mathrm{H} 17$; report $\mathrm{Ph}$. J. van Zuylen van Nijevelt 1825, Algemeen Rijksarchief, The Hague [hereafter ARA], collection Ph. J. van $Z$. van $N$. no. 109; report Commandant Wikkerman 1805, ARA, coll. van Alphen-Engelhard (1916) no. 149/155.

The price paid for the slaves in Bali was between 20 and 45 rijksdaalders, whereas the selling price in Batavia was about 100 rijksdaalders; see Lekkerkerker, "Bali," p. 326. On the population of Batavia, see C. Lekkerkerker, "De Baliërs van Batavia," Indische Gids [hereafter $I G$ ] 40 (1918), pp. 409-32, especially pp. 416-18. Even today there still is a Kampung Bali in Jakarta.

6. On European intermediaries in Buleleng (North Bali) in the seventeenth century, see H. J. de Graaf, "Gusti Panji Sakti, vorst van Buleleng," Tijdschrift voor de Indische Taal-,Land-en Volkenkunde van het Koninklijk Bataviaasch Genootschap van Kunsten en Wetenschappen [hereafter $T B G$ ], 83 (1949), pp. 59-82. Some pre- 
Kuta, with its two harbors on the east and west side of Bali's southern peninsula, became the most important place for the purchase of this human cargo. ${ }^{7}$ Furthermore, there is no doubt that the Balinese rajas controlled the greater part of this export of human labor, and that their local power depended largely upon this trade.

\section{Major Changes}

An important shift in the export pattern of Bali came at the beginning of the nineteenth century. Two events were responsible for this break with the past: the disastrous eruption of Tambora on the island of Sumbawa in April 1815, and a new colonial policy, initiated by Raffles, which gradually stopped the slave trade in the Indonesian archipelago. The eruption of Tambora with its enormous ash rain initially caused widespread crop failure, epidemics, and starvation on Bali and Lombok, although after several years it brought new fertility to the islands. ${ }^{8} \mathrm{Ob}-$ struction of the slave trade by successive colonial administrations in Batavia eliminated a considerable part of the income of the Balinese rajas, who now found their wealth and power threatened from both sides: from their agrarian environment and from their slave-trade contacts.

Nevertheless, the recovery of the Balinese economy and exports was remarkable and fast. There are some indications that, before 1815 , Bali regularly had to import rice from Java and Lombok; ${ }^{9}$ but, from 1825 , the island was exporting ever increasing quantities of rice. Bali's exports also included coconut oil, dendeng (dried meat), pigs, hides, coarse cotton cloth, and tobacco.

Two external factors stimulated this new commercial activity: first, an almostconstant Javanese demand for food products as a result, initially, of the Java War and, later, of the introduction of the Culture System; in the second place, the rapid growth of the Singapore trade, ${ }^{10}$ which eventually was to link Balinese supply with Chinese demand. Already in 1825, for instance, José d'Almeida, son

liminary observations on the Balinese slave trade in the seventeenth and eighteenth centuries appear in Nordholt, "Macht, mensen en middelen," ch. 2 .

7. Report Intje Boeang 1805, in "Bali 4, 3," Residency archives, Arsip Nasional Republik Indonesia [hereafter ANRI]. I am grateful to the staff and especially to Dra. Mona Lohanda of the ANRI for providing me with valuable reports on nineteenth century Bali. See also Johannes Olivier, Land-en zeetogten in Nederlandsch Indië 1817-1826, 1 (Amsterdam: Sulpke, 1827), p. 478.

8. On the eruption, see Anon [H. A. van den Broek], "Verslag nopens het eiland Bali," De Oosterling, 1 (1835), pp. 158-236; Olivier, Land-en zeetogten, ch. 25 ; report P. Dubois September 5, 1829, ARA, Archives Ministerie van Koloniën [hereafter MvK] V January 8,1857 no. 27; a summary of reports concerning the Tambora eruption in Verhandelingen Bataviaasch Genootschap van Kunsten en Wetenschappen [hereafter $V B G$ ], 8 (1816). There are no reliable figures on the total number of deaths.

9. [Van den Broek], "Verslag"; J. C. M. Rademacher, "Korte beschrijving van het eiland Celebes en de eilanden Floris, Sumbauwa, Lombok en Baly," VBC, 4 ([1786] 1824), pp. 143-96, especially p. 188; D. van Hogendorp, Berigt van den tegenwoordigen toestand der Bataafsche bezittingen in Oost-Indiën en den handel op dezelve (Delft: Roelofswaert, 1799), pp. 191-92.

10. See Wong Lin Ken, "The Trade of Singapore 1816-69," Journal of the Malayan Branch of the Royal Asiatic Society [hereafter JMBRAS], 33, 4 (1960). 
of the founder of the d'Almeida trading house in Singapore, shipped Balinese rice to China, ${ }^{11}$ but most of the trade was still conducted by Buginese and Chinese monsoon traders who came with their prahu from Java, Makasar, and Singapore, and lived in small communities in and around Kuta.

On the Balinese side of the trade, two other important factors caused an economic change in the $1820 \mathrm{~s}$. Several years after 1815 , the thick coat of ash which covered the island began to develop higher soil fertility. ${ }^{12}$ Second--and probably more important, though it is at the moment speculative because direct evidence is lacking--the Balinese rajas changed their attitude towards the export trade. Instead of selling their subjects, they began to use their labor to produce export crops. At the same time they were able to adapt to new demands in the archipelago. They did not only expand the existing production of rice, coconut oil, and meat, but also introduced new products like tobacco and coffee. About twentyfive years later G. W. Earl observed that "in fact Bali is . . remarkable among the neighbouring countries for the production of articles suited for the consumption of the Archipelago." 13

The active concern of Balinese rajas with these changes is to be inferred from the fact that the supply of these export products on Bali was adapted to new demands, and from numerous references to the rajas' retention of a firm grip on the sea trade. One report even notes that the raja of Gianyar (South Bali) had started growing tobacco in his own gardens. The same report also mentions the monopoly on packhorses, which brought the local produce to the harbors, so that the inland rajas and lords virtually controlled all the external trade. ${ }^{14}$

\section{Balinese Politics and Foreign Trade}

Between members of the Balinese elite there was a continuous, complex, and dynamic struggle for better positions. Descent, marriage, titles, followers, poison, endless intrigues, and eventually wealth and weapons were all tools to be used in a fight for temporary superiority both within the family and between different noble "houses." Even a slight advantage could be decisive until one was challenged by someone else. Such striving for power and status marked Badung politics and, more broadly, all Balinese politics. As an observer, who lived for one year in Kuta, wrote in 1840 :

11. Ch. B. Buckley, An Anecdotal History of Old Times in Singapore, 1 (Singa pore: Fraser \& Neave, 1902), p. 187.

12. Report P. Dubois September 5, 1829, ARA, MvK V January 8, 1857 no. 27; John Crawfurd, Descriptive Dictionary of the Indian Islands and Adjacent Countries (1856; Kuala Lumpur: Oxford University Press, 1971), p. 219 and p. 28 where he writes that the increasing export of rice was "a creation of recent years"; R. B. G., "Bali: A Gallop to the Bukit," Journal of the Indian Archipelago [hereafter $J I A], 5$ (1851), pp. 367-73.

13. G. W. Earl, "The Trading Ports of the Indian Archipelago," JIA, 4 (1850), pp. 530-31, p. 541 .

14. Report of the Inspector of Finances, De Linge, September 30, 1838, ARA, MvK V January 29, 1842 no. 43 geh. See also Elizabeth Graves and Charnvit Kaset-siri, "A Nineteenth Century Siamese Account of Bali," Indonesia, 7 (April 1969), pp. 77-123. Though this account concerns North Bali in 1846, and the Siamese trader was allowed to enter the hinterland himself--which is, I think, an exception--the story shows clearly the firm grip of the raja on the local and external trade. 
Since my first arrival here, I had given myself the task of gaining a picture of the relationships between the rajas themselves and between them and the Tjokorda [Dewa Agung]. In particular about the two main rajas and the lesser rajas in Bali Badung; furthermore about the way of their government, their power etc. The more I learned about it, the more I noticed that I became entangled in a labyrinth of complex family relations and interests. All this became even more complicated by the divergence of information, which was given differently, as one received it from the royal lineage of Pametjutan, Den Pasar, Kesiman or anyone else. ${ }^{25}$

The three royal descent groups of Pamecutan, Den Pasar, and Kesiman competed continually among themselves for power in the South Balinese "kingdom" of Badung, and good relations with the sea trade were vital to obtain that power. As P. Dubois, the excellent observer of Balinese politics around 1830, noted, "l'argent est le nerf du pouvoir." 16 As early as about 1800, "queen" Gusti Putu Agung, the leading lady of the royal descent group of Pamecutan, had built houses in Kuta for Chinese and Buginese traders to attract trade and wealth. ${ }^{27}$ A newspaper account in 1828 tells how at that time the different royal descent groups of Badung were striving to attract and control more trade than their rivals. It states that when a foreign trader arrived at Kuta, he was immediately asked by the agents of the Badung lords whether he wanted to become a subject of one of them. And once the stranger had chosen one of the lords, he received his protection. But the trader also had the obligation to stay loyal to that lord, for, if he dared to change his mind and allegiance, the probably result was fire-raising, plunder, or murder. ${ }^{18}$

During the 1830s it was the strong Gusti Ngurah Gde Kesiman who gradually took the lead in Badung, and when an envoy of the Dutch Trading Company (NHM) came, looking for a suitable location for a factory on Bali or Lombok, this energetic raja eagerly invited him to settle down in Kuta under his protection. ${ }^{19}$ The same raja had also tried to improve the roads between Kuta and the neighboring areas of Tabanan, Mengwi, and Gianyar in order to stimulate trade. He failed because of lack of cooperation; most people were reluctant to help, as only a few would profit from these improved communications. ${ }^{20}$ Nevertheless, all these attempts indicate the local elite's interest in profitable trade contacts.

The success of foreign traders in Kuta depended entirely upon the protection provided by one of the strongest local rajas. Furthermore, their role was strictly

15. D. B. Schuurman, "Verslag factory Koeta 1840," ARA, Archive Nederlandsche Handels Maatschappij [hereafter NHM], reisverslagen en rapporten.

16. "Money is the key to power," P. Dubois, KITLV Leiden, H 281, XII. On the organizing principles of the Balinese elite, see Geertz, Negara, ch. 2. It is a pity, however, that Geertz did not pay any attention to archival material. For the political constellation of Badung 1800-1840, see Nordholt, "Macht, mensen en middelen," ch. 4.

17. She even played cards with these men. See P. Dubois [ \pm 1833$]$, ARA MvK no. 3087 , III.

18. Javasche Courant, July $3,1828$.

19. Report C. A. Granpré Molière February 14, 1839, ARA, MvK V January 29, 1842 no. 43 geh.

20. P. Dubois, KITLV, Leiden, H 281, XII ; idem, report February 27, 1831, ARA, MvK V January 29, 1842 no. 43 geh.; Nordholt, "Macht, mensen en middelen," pp. $101-4$. 
confined to the coastal areas. A place like Kuta functioned itself, in a way, as a broker. There, through Chinese middlemen and Balinese women, transactions took place, while at the same time the foreigners were separated from the inland economy (for they were not allowed to come beyond the shore). As one report says:

A European merchant, coming to Bali, has to address himself to the raja by way of the shahbandar [harbor master] if he wants to achieve anything. And only after the raja has made his choice for himself and for those who belong to him, may the merchant start his business. This has to be conducted by giving credit to Balinese women, who will carry the goods around in the hinterland. This may take two and sometimes three months. ${ }^{21}$

The outside world was needed, used, and therefore permitted to stay at Kuta, but it was not allowed to interfere in internal affairs. As was noted above, however, the system did not work perfectly. Although, during the 1830s, raja Kesiman tried to strengthen his grip on Kuta's commerce, he was not successful in his efforts and competition for the total control of the sea trade continued among the members of the Badung elite. An attempt to reorganize the system of shahbandar, with Kesiman monopolizing the European contacts, provoked retaliation from his opponents. ${ }^{22}$ When P. Dubois, who was a Dutch colonial agent in Kuta from 1828 till 1831, was asked by his superiors about the possibilities for future trade by Europeans, he gave negative advice. In May 1831 it was decided to withdraw the Kuta agency, largely because raja Kesiman did not seem able to exercise enough control over the place. ${ }^{23}$ Political outcasts and refugees from other parts of the island were allowed to find a living on this edge of the island.

This was the world that Mads Lange was to enter. An important shift was then taking place from the export of slaves towards the export of crops; virtually all trade was controlled by the local elite; the different members of this elite competed vehemently among themselves for a larger share of the profits from this trade; and the role of foreigners was strictly confined to places like Kuta. Mads Lange entered an existing system of dealing with foreigners, where the room to maneuver between Bali and the outside world was limited, but offered important opportunities.

\section{The Lombok Trade}

Mads Johansen Lange (September 18, 1806-May 13, 1856) ${ }^{24}$ was born in Rubk $\phi-$ king, on the island of Langeland, Denmark. He grew up in a merchant family, and

21. Report De Linge, September 30, 1838, ARA, MvK V January 29, 1842 no. 43 geh.; see also Anon., "Island of Bali," Chinese Repository, 4 (1835-36), pp. 450-61, p. 457: "Presents are also looked for by the rajah, if visited, and by his great men, if any business is to be done with them," and p. 451: "The women are the merchants, and often the carriers of their wares."

22. Report P. Dubois, May 28, 1831, ARA, MvK V January 8, 1857 no. 27. Before Kesiman's reorganization there were twenty to fifteen shahbandar, each belonging to different members of the Badung elite and covering specific, though sometimes overlapping, fields of trade. These men, recruited from the lower elite, were now dismissed by Kesiman. Instead of them he appointed only one Chinese and one Buginese for their respective communities in Kuta, whereas he himself was responsible for the European traders.

23. Decision Governor-General January 28, 1831, ARA, MvK, Resolutions G.G.; Dubois' task had been to enlist slave-soldiers, badly wanted by Batavia in the war against Diponegoro.

24. L. C. Heyting, "Het graf van den Deen Mads Johansen Lange," Koloniaal 
in 1824 , when he was eighteen, he went to sea as a crew member on one of the ships of the Danish Asiatic Company. In the 1830s the Danish Company sold many of its ships, and one of them, the Syden, was bought by Captain John Burd, who planned to trade along the China coast. He left Denmark in 1833, and his second-in-command was Mads Lange. Three brothers of Mads--Hans, Karl Emilius, and Hans Henrik--were also members of the crew. ${ }^{25}$

For a short period John Burd and the Lange brothers were employees of the trading house of Jardine, Matheson, and Co., but very soon they started a small company of their own: Burd and Co. ${ }^{26}$ The Burd Company had its main base on the island of Lombok, and from 1834 Mads Lange, as the company's agent, lived in Ampenan, the west coast harbor of the island.

The importance of Lombok in the system was based on its export of huge quantities of cheap rice, combined with its strategic location on existing and new trade routes. Roughly speaking, three levels of trade were routed through Lombok. First, the "European" trade, by which I mean the trade conducted by European ships, such as schooners and brigs, but not necessarily with Western crewmembers, captains, or even owners. Longer distances and bigger quantities of cargo characterized this trade. Lombok--and later Bali--lay on the routes New South WalesManila-China, and New South Wales-Singapore-Bengal (and even Europe). Another route ran from Lombok to Mauritius and the Cape Colony. The second level consisted of "ordinary" monsoon trade by Chinese and Buginese prahu between Lombok, Java, Makasar, Riau, Kalimantan, the Moluccas, and Singapore. The third level was local, between the neighboring islands of Bali, Sumbawa, Timor, Alor, etc.

Ampenan, the main Lombok harbor, became an important supplier of rice to markets in China, Singapore, and Australia, with only a small portion exported to Java. American and English whalers from the Indian Ocean also bought rice and other foodstuffs, making regular calls at the island for provisioning. The Lombok rice market became a kind of staple market, where products from the neighboring islands were brought, and from there exported to China, Singapore, Mauritius, etc. However, cheap rice remained the main export product which made the harbor of Ampenan generally known and visited by traders in the archipelago. ${ }^{27}$

John Burd and his partner Mads Lange based their activities almost entirely upon this export of rice. The trade was simple but profitable. Lange gathered rice from the Lombok hinterland, and Burd exported it to Canton. There it was exchanged for Chinese coins (kèpèng or picis), the local currency on Bali and Lombok. ${ }^{28}$ This trade prospered, and after a few years Lange and Burd were also selling their rice on the Singapore market, in exchange for textiles, opium, and

Weekblad, May 7, 1925. Another birth date given is September 18, 1807; see van Naerssen et al. , Catalogue, p. 149.

25. Aage Krarup Nielsen, Leven en avonturen van een Oostinjevaarder op Bali (Amsterdam: Querido, 1928 [trans.]). The four Lange brothers all died on Bali.

26. Schuurman, "Verslag 1840."

27. Already in 1837 G. W. Earl had noted that the island of Lombok was "more frequently visited by British ships than any other native port in the Archipelago, as vessels from New South Wales often call here on their voyage to China for the purchase of rice," George W. Earl, The Eastern Seas (London: Allen, 1837), p. 90.

28. On kèpèng imports and their exchange value, see below $\mathrm{n}$. 41 . 
weapons. They bought a second ship, the Falcon, a former brig of the East India Company. Other vessels soon followed. At the same time, Lange began to organize the Ampenan staple market, by buying local produce on neighboring islands. ${ }^{29}$

However, Mads Lange was not the only European who sought a possible fortune on Lombok. George Peacock King, an Englishman and former partner of the Wilson, Smith and Co. trading house in Batavia, also settled at Ampenan in 1834. His main connections were with Singapore, and his trade consisted of exporting rice in exchange for opium, textiles, weapons, iron, and luxury goods.

In the beginning there was room enough for both Lange and King. They advertised their cheap Lombok rice in newspapers in Singapore, China, and Australia, and their presence at Ampenan soon attracted many "European" ships. In 1835, fifteen English and three French vessels were seen at the same time lying off the coast of Ampenan, and five years later twenty-five English ships were at anchor there simultaneously. ${ }^{30}$ Different reports mention a yearly export of 10,000 to 14,000 tons of rice at a price of 60 guilders per koyang. ${ }^{31}$

The "European" level of trade was in the first instance responsible for the larger quantities of rice which were being exported via Lange and King. Earl noted that they

soon attracted British vessels that had taken out emigrants to Australia, and were on their way to the Indian ports to obtain return cargoes for Europe. These would often obtain a freight to China, the Mauritius, Singapore, and sometimes to England. ${ }^{32}$

Both traders were protected by the strongest of the two dominant royal descent groups of Lombok, Karangasem-Lombok. Though King and Lange had no monopoly on the trade--they were not even shahbandar--without doubt they made good profits. There is also no doubt as to the advantages for the royal family under whose protection this trade was conducted. One of the three shahbandar of Lombok, the Karangasem-Lombok shahbandar, had to pay his raja 10,000 guilders a year. In addition, King "bought" the raja's permission to trade in Ampenan at a price of 2,000 guilders a year. If the numerous unofficial gifts and the credit which was given away as "investment" are added to these figures, the conclusion must be that the royal profits were considerable. ${ }^{33}$

Dynastic Struggle and Lange's Loss

At the beginning of 1838 a dynastic struggle broke out between the two dominant royal descent groups on Lombok: Karangasem-Lombok and Mataram. Lange

29. Schuurman, "Verslag 1840."

30. Nielsen, Leven en avonturen, pp. 22-23; C. Lekkerkerker, "Het voorspel der vestiging van de Nederlandsche Macht op Bali en Lombok," $B K I, 79$ (1923), pp. 198-322; Schuurman, "Verslag 1840"; report Assistent Resident [hereafter AR] of Banyuwangi, ARA, MvK V November 25, 1836 no. 6/632; Earl, "Trading Ports," pp. 396-99; Anon., "Handel van Lombok," Nautical Magazine [London] (1843), pp. 816-31.

31. A koyang was about two tons. So, the rice cost 30 guilders per ton. Report S. J. Wetters September 11, 1838, ARA, MvK V January 29, 1842 no. 43 geh.; Anon., "Handel van Lombok," pp. 816-31.

32. Earl, "Trading Ports," p. 397.

33. Every Lombok royal descent group had its own shahbandar in Ampenan; Report AR Banyuwangi, ARA, MvK V November 25, 1836 no. 6/632. 
and King became involved in this war, which lasted until the middle of $1839 .{ }^{34}$

At the outset, both calculated the probable outcome of the fight. King chose to support Mataram, the weaker side, whereas Lange thought it unnecessary to display great activity because his protector, the raja of Karangasem-Lombok, had by far the largest following. King, however, started a large-scale transport of troops from Karangasem-Bali to Lombok. Allied parties in Karangasem-Bali mobilized 6,000 to 8,000 men and sent them, by way of King, to their Mataram friends on Lombok. Even Lange participated in this enterprise, though it was against his own protector. In doing so he dug his own grave.

After initially trying to make the war profitable for their own commercial interests, Lange and King gradually became involved in the actual fighting. They had no choice if they did not want to lose their trade, protection, and credit in the rice-growing hinterland. In the beginning, after a day of small-scale skirmishes, Lange and King would regularly come together at night to have a drink and a cigar, but by the end they had become enemies. ${ }^{35}$ The war resulted in a victory for Mataram, mainly because the troops transported from Bali by King and Lange altered the balance of power. Karangasem-Lombok's followers left their masters for the winning Mataram side, which retained hegemony over Lombok until destroyed by the Dutch in 1894. ${ }^{36}$ For the first time, Europeans had exerted a decisive influence on Balinese politics. As they had previously increased the scale of the region's trade, so now they had expanded the use of force in its politics.

As a reward for his assistance King received the position of shahbandar and the monopoly of the rice and opium trade. He also became the raja's first adviser on matters concerning Lombok-Dutch relations.

Lange had lost the fight, his factory, most of his ships (which had been sunk or captured), and, in short, his trade. He had also lost 30,000 (Spanish) dollars spread among the vanished following of Karangasem-Lombok. He did not accept the honorable invitation to participate in his protector's puputan (i.e., the ritual suicide of the royal family), but left the island with his schooner Venus, the only ship he had been able to save. He sailed to Kuta to start anew.

\section{The Kuta Trade of Mads Lange}

At the end of 1839 , Lange settled down near Kuta and, within a few years, he had again developed a prosperous trade which was to last till the beginning of the 1850 s. The factory he built near Kuta became a busy exchange. Surrounded by a huge wall with an imposing gateway, the complex contained warehouses, dwelling-

34. Although there were kinship ties between the rajas of Karangasem-Bali and those on Lombok, the latter were politically virtually independent and during the 1840s serious antagonism arose between them. For accounts on the 1838-39 war on Lombok, see Lekkerkerker, "Voorspel"; report H. J. Huskus Koopman February 13, 1841 , report $\mathrm{C}$. A. Granpré Molière February 14,1839 , and report $\mathrm{S}$. J. Wetters September 11, 1838 in ARA, MVK V January 29, 1842 no. 43 geh.; and Schuurman, "Verslag 1840."

35. Van Hoëvell, Reis, 2, p. 181.

36. On the events on Lombok in 1894, see A. van der Kraan, Lombok: Conquest, Colonization and Underdevelopment, 1870-1940 (Singapore: Heinemann, 1980), and J. van Goor, "Dutch Imperialism in Indonesia during the Administration of G.G. C. H. A. van Wijck," Paper delivered at the second Indonesian-Dutch Historical Conference, Ujung Pandang, June 1978. 


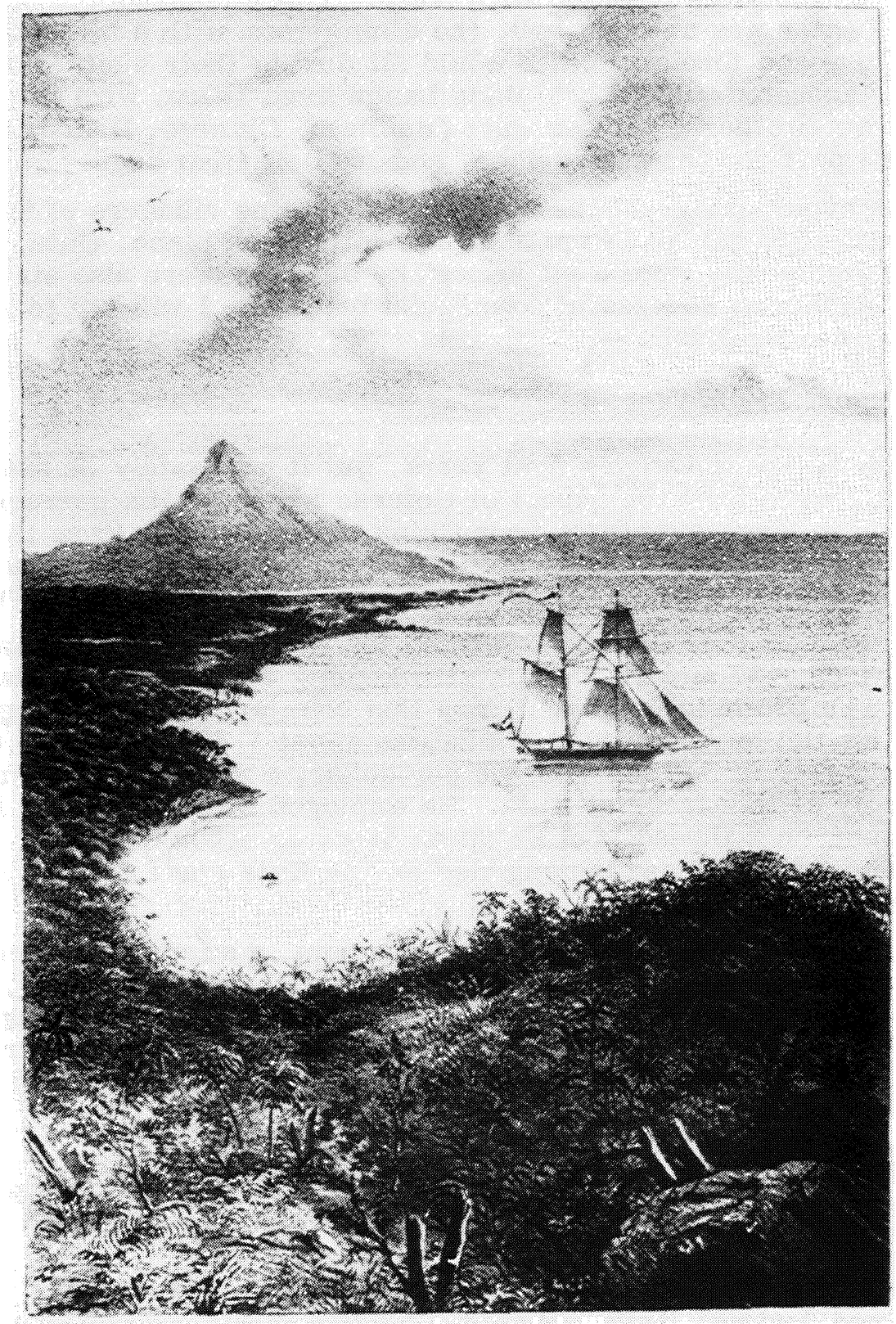

PLATE II: Lange's schooner "Venus" 
places, and a market-place planted with trees. There transactions normally took place. In the center was an open hall, the dining room with a billiard table, where the many Balinese and foreign guests would sit during their visits. ${ }^{37}$ The factory looked like an "animated village." ${ }^{38}$ Mads Lange lived there, with his Balinese and Chinese nyai, his brothers, his servants (Balinese, Chinese, Danish, English, and others) from all parts of the archipelago, and his Dalmatian dogs. ${ }^{39}$

During the evenings, when the work was done, the villagers of Kuta could hear Danish folk music, played by Lange and his brothers on piano, flute, and violin. They were strangers who were a bit homesick, but they were also strangers who were able to function as successful commercial brokers. I will try to analyze this brokerage now in more detail.

The Kèpèng Import Trade

Little is known about Lange's first years, but it may safely be assumed that his major profits came from the import of Chinese kèpèng. His partner John Burd sent these coins in large quantities from China to Singapore. From there Lange brought them, together with opium, textiles, iron, weapons, and luxury goods to Kuta. Rice was the most important Balinese export in this triangular trade circuit.

Ludvig Helms, another Dane who worked for two years in the Kuta factory, wrote that between 1847 and 1849 ships with kèpèng cargo very regularly entered the harbors. The profit to be gained from this coin lay in its exchange value. During the 1840 s the buying rate in China was about 1,400 kèpèng to the dollar, while the selling rate in Badung was 700 per dollar, a profit of 100 percent. Lange had the monopoly of this trade at Kuta. He employed Balinese women in his factory to put 200 kèpèng on a thread to make up an atak, an accounting unit for the larger amounts of currency. ${ }^{40}$ These kèpèng tied all the Kuta trade together. As Earl wrote:

Produce is generally purchased with this coin, a supply of which is constantly kept on hand by the Bandars . . . of the various ports, who furnish them to traders in exchange for Spanish dollars or Java rupees;--and at Badong, Treasury or Navy Bills are readily negociated by Mr. Lange. Even when goods are given in exchange for produce, a price in Chinese cash is fixed on each. ${ }^{41}$

37. Ludvig V. Helms, Pioneering in the Far East (London: Allen, 1882), pp. 13-14.

38. Van Hoëvell, Reis, 2, p. 181.

39. Mads Lange had three children. From Ni Kenyèr, his Balinese nyai from Tabanan, a boy named Andreas Emile, who later became the secretary of Raja Brooke of Sarawak; from Sang Nio, his Chinese nyai, a girl, Cecilia, who married Sultan Abu Bakar of Johor after 1860. Another son, William Peter, died when he was very young. Nielsen, Leven en avonturen, pp. 212-21.

40. Helms, Pioneering, p. 40. Huge quantities of kèpèng were normally counted by strings of $200 \mathrm{k}$. each.

41. Earl, "Trading Ports," p. 543. Already in 1835 a French ship from Mauritius exchanged 10,000 Spanish dollars for kèpèng in Bali. Report AR Banyuwangi, ARA, MvK V November 25,1836 no. 6/632. On the penetration of the kèpèng in West Java, see L. Blussé, "Troyan Horse of Lead, the Picis in Early 17th Century Java," in Between People and Statistics, ed. F. van Anrooy et al. (The Hague/ Amsterdam: Nijhoff, 1979), pp. 33-40. On the kèpèng at the beginning of the 
It seems that kèpèng imports met an existing need in an established monetary circuit on Bali, but the new influx, now organized by Lange, definitely stimulated the further monetarization of the inland economy. There are even some indications that the constant import of new kèpèng caused inflation on the island. For, whereas in 1836 the selling rate of the coin was $600: 1$, and during the 1840 s 700-750:1, during the 1850s it was already 1200:1, although the exchange value in China remained the same. ${ }^{42}$

Through his monopoly of the import of kèpèng into South Bali Lange gained easy entry to the Balinese market and the exclusive kèpèng-rice exchange formed the main material basis of his activities as a broker and of his profits.

\section{Brokerage}

A second aspect of Lange's role in becoming an exclusive channel, needed by both sides, lay in his success in establishing an entrepôt at Kuta. He was able to raise and maintain stocks large enough to put on board the many ships which came to Kuta, so that only a short time was needed to load the cargoes.

The factory had become a vital hinge between the local economy and the interAsiatic trade. To participate in the inter-Asiatic branch of the trade Lange had several "European" ships at his disposal. Other ships were used to gather the local produce from neighboring islands, such as Lombok, Sumbawa, Flores, Bima, and Timor, and from such small Balinese harbors as Sesih on the southwest and Padang on the southeast coast. Lange had his agents and storehouses in these places. His agents were mainly Chinese, who organized the local interisland trade centered on Kuta. It is said that, in total, Lange owned between nine and twelve vessels for the local and long-distance trade. ${ }^{43}$

Lange had a really large business during the 1840s and many "European" ships anchored throughout the year in the west or east bay of Kuta to buy rice and other goods from him. King, his business rival on Lombok, retained the largest yearly export of rice (between 16,000 and 20,000 tons, at a price of between 40 and 60 guilders per ton); Lange exported between 5,000 and 12,000 tons a year. ${ }^{44}$ But,

twentieth century, see P. de Kat Angelino, "De kepeng op Bali," Koloniale Studiën, 5 (1921), pp. 67-84.

42. Report A. C. Edeling December 13, 1836, ARA, MvK V January 29, 1842 no. 43 geh.; Anon., "Island of Bali"; Alfred R. Wallace, The Malay Archipelago (New York: Harper, 1869), p. 185; report J. H. Peter 1856, ARA, NHM, reisverslagen en rapporten. The inflation may have been stimulated by the import of new kèpèng produced in Singapore in the 1850 s.

43. See Helms, Pioneering, p. 39; Earl, "Trading Ports," p. 535; R.B.G., "Bali," p. 370 ; report J. H. Peter 1856, ARA, NHM. At the beginning of the 1840 s the Burd Company was dissolved and both Burd and Lange continued their own trade. It is not altogether clear whether Lange owned all the ships himself, or whether he hired some of them. Another possibility is that Lange contracted ships and captains, who gradually became--or already were--indebted to him: a patron-client relationship. New vessels bought by Lange were probably built in Singapore.

44. Earl, "Trading Ports," pp. 535, 541; H. Zollinger, "Het eiland Lombok," Tijdschrift voor Nederlandsch Indië [hereafter TNI] (1847), 2, pp. 177-205, 301-83, especially p. 312; Anon., "Handel van Lombok," pp. 816-31; memo G. P. King \pm 1847 , ARA, coll. A. H. W. de Kock no. 1. Zollinger gives a very detailed report on the Lombok trade. 
besides rice, Lange sold large amounts of coconut oil in Singapore with a profit of 200 to 300 percent. Furthermore, the export of animals, dried meat, hides, cotton, tobacco, and coffee developed rapidly; next to kèpèng, it was textile imports that increased the most. ${ }^{45}$ The total trade between $\mathrm{Bali} /$ Lombok and Singapore increased from $\$ 140,342$ in $1829-30$ to $\$ 572,512$ in $1843-44,{ }^{46}$ and a higher figure should be given for the year 1847 when both King and Lange probably had reached the height of their success.

Mads Lange had become the shahbandar of raja Gusti Ngurah Gde Kesiman, and in this capacity he controlled nearly all the Kuta trade. As Earl noted:

There are no Port charges on vessels anchoring merely to obtain intelligence. Dues amounting to a few dollars are levied on ships coming for water and refreshments. The import and export duties which are exceedingly moderate are levied through $\mathrm{Mr}$. Lange, who farms this branch of revenue from the government, and is thus enabled to afford greater facilities to European traders than if the collection was in the hands of the natives themselves. A lithographed copy of the Port Regulations is put on board every vessel on her arrival, in fact affairs are managed with the same regularity as in a well-conducted European Port. ${ }^{47}$

At least some order was introduced in Kuta, to the benefit of both Lange and his protector, raja Kesiman.

Even more important was the Balinese portion of the trade. Only very few Europeans lived for a long period of time in the factory. Apart from Mads Lange and his brother Hans, there was a doctor, a clerk and, later on, Ludvig Helms. They organized the transactions and the supply of inland products.

Lange's stocks were built up mainly from many small supplies. "All these things were bought in the establishment from natives who carried them thither, or were sent by Chinese traders and agents employed on the coast." 48 Balinese noblewomen also played a crucial role in the trade, acting as Lange's inland agents and providing the larger part of the Balinese export products. As noted above, no Europeans were allowed to participate in this inland trade, and Lange adhered strictly to this existing rule. As Helms observed: "Mr. Lange, probably influenced by the spirit prevailing around him, had an objection to employing Europeans on shore, though he had many afloat." 49 Lange obviously did not want to interfere in the inland trading system. Apart from himself, and sometimes his brother Hans, no one was allowed into the interior. In addition to observing the existing separation, he was probably aiming to avoid possible conflicts between illmannered Europeans and Balinese; and, indeed, direct European influence appeared unnecessary. To quote Helms again at some length:

[when a French ship arrived for the purchase of animals] it was only necessary to send [notice] a few days in advance to a dozen or so of the Balinese

45. Wong Lin Ken, "Trade of Singapore," gives in Table 3, pp. 259-62 a total of Singapore $\$ 14,702$ of textiles exported to Bali and Lombok in 1836, and a total of $\$ 54,153$ in 1846 .

46. Ibid., Table 7, p. 219. After 1846 there are no separate figures for Bali and Lombok.

47. Earl, "Trading Ports," p. 535.

48. Helms, Pioneering, p. 39.

49. Ibid. 
ladies, who acted as our agents in such matters, and on the appointed day, the beach near which the vessel lay would be crowded with many times the number of animals wanted. . . . it required some discretion to distribute patronage amongst our friends to their satisfaction. . . . Here, for instance, is . . Anak Agung. . . She is the wife of Gusti Mate Dangin, a noble of rank. She has come many miles this morning with her ponies and attendants. . . How can her pleading be resisted? But, on the other hand, there is Meme Kintang . . . who pleads her long business relation with energy, while a third screams that, last time her oxen were shut out in favour of her sister merchants. . . at this juncture Mr. Lange makes his appearance, when they all in chorus appeal to him, who, most likely, in his usual offhand way, consents to take all, to the great embarrassment of the unfortunate clerk, who .. . finds that he has two or three times as many animals on his hands as the ship will hold. . . . ${ }^{50}$

Apart from Badung, the hinterland encompassed also the neighboring areas of $\mathrm{Ta}-$ banan, Mengwi, and Gianyar. This formed a rich area to which Lange had almost open access.

\section{Personal Relationships}

An even more important aspect of Lange's position was his ability to maintain many personal relationships, not only with his Chinese and Balinese agents, but also with the local elite and possible opponents. He understood the social atmosphere in which he had to act, and so he could solve problems in a generous way before they evolved into crises which might have threatened him. In order to do this Lange had to "invest" a lot of credit in the local elite, to buy protection, confidence, and goodwill. By such means he survived in the still dangerous Kuta. Often he had no choice but to ward off conflicts by appeasing with opium and money latent local resistance from impoverished nobles at Kuta, or, in case of shipwreck, to buy off elements of the local population who were intent on looting the ship. For instance, when in 1841 one of his Chinese servants hit a Balinese, his factory was besieged for four days by a Balinese mob under leadership of a local "bandit," who wanted to set fire to the buildings. Only through a gift of several balls of opium and 200 guilders was Lange able to buy peace. ${ }^{51}$

A nice example of the way Lange dealt with "ad hoc" situations was his rescue of Dr. W. R. van Hoëvell's spectacles on his visit to Bali. Lange introduced van Hoëvell to the old, half-blind and cross-eyed Pedanda Agung ("court priest") of Badung as "the Pedanda Agung" from Batavia. The man was very honored to meet his European equal and wanted to try on van Hoëvell's spectacles. They suited the old priest and he did not want to give them back. Lange solved this problem by saying that these spectacles were only fit for younger people, not for old men. "With these spectacles," he said, "the light in your eyes will flare up only for a moment, just as the light in a lamp before it dies out." 52

"Gde Lange," as he was called, became a rich man. Gifts and profits went hand in hand. Gifts to appease his environment, profits when, from time to time,

50. Ibid., pp. 41-43.

51. Govert Blom, Lotgevallen op mijne reis naar Java ([Batavia?]" n.p., 1841), pp. 61-63; Anon., report in ARA, coll. A. H. W. de Kock no. 1. The "bandit" was Gusti Ngurah irtut a lower relative of raja Kesiman (his half-brother's youngest son), who had gradually lost his grip on the opium trade in Kuta.

52. Van Hoëvell, Reis, 3 (1854), pp. 59-60. 
he got good prices. But it was all very erratic; indeed, if his clerk made any effort to keep precise records, he must have felt miserable.

\section{Lange as "Perbekel"}

A last component of Lange's function was his relationship with the raja of Badung. Among the three rival royal descent groups, raja Kesiman had climbed to the top. He had the largest following and kept the other competing groups well under control. To maintain a following required means, beyond marriage alliances and the use of land. From Lange's commercial activities raja Kesiman not only received the yearly rental of the shahbandarship and percentages of the import and export duties levied at Kuta and the inland borders, but also other advantages in the "unofficial sphere": gifts, guns, opium, luxury goods, etc. Furthermore, raja Kesiman was nowable to exercise more control over the Kuta trade, by protecting one particular man who was in a physically weak position.

In order to give Lange a more comprehensible status, Kesiman made him his perbekel, a Balinese rank denoting a local authority/follower of the raja, in Kuta. ${ }^{53}$ Kesiman's protection was indispensable for Lange. Being under the raja's protection enabled him to expand his trade. By protecting his trader, raja Kesiman received the extra means for increasing his political power and maintaining a larger number of followers. Their mutual, but separate, benefit, without doubt formed the most important personal base of Lange's existence in Kuta.

Lange did not interfere in Balinese politics. His field was trade. In this respect he was that vital hinge between the outside world and Bali, a commercial broker. The monopoly of kèpèng imports, his entrepôt at Kuta, the organization together with the separation of two kinds of trade, and his expensive but balanced relationships with his environment were all parts of the economic side of the Mads Lange connection.

\section{Dutch Interference and Balinese Politics I: The Diplomatic Offensive}

The activities of George P. King and Mads Lange on Lombok, and their private participation in the dynastic struggle in 1838-39, did not pass unnoticed. Rumors mixed with a profound paranoia were the main stimuli for the policy pursued by Batavia and The Hague, a policy which, after a diplomatic offensive, eventually led to three useless military expeditions against Bali, or, more precisely, against a nonexistent enemy: the English.

The "colonial paradox" which marked the period of the Culture System ${ }^{54}$--on the one hand, a policy of noninterference and on the other, military expeditions against areas in the "Outer Islands"--is fully applicable to Batavia-Bali relations .

By the 1824 Treaty of London the Indonesian archipelago was divided between the Dutch and the English, but this division was not "watertight" because the

53. K., "Een bezoek bij den Radja van Beliling op het eiland Bali," Tijdspiegel (1849), 1, pp. 213-26, especially p. 215 .

54. See C. Fasseur, "Een koloniale paradox, de Nederlandse expansie in de Indonesische archipel in het midden van de $19 \mathrm{e}$ eeuw, 1830-1870," Tijdschrift voor Geschiedenis, 92 (1979), pp. 162-86. A resolution of the Governor-General of November 30,1830 strictly forbade colonial officials from interfering in local politics in the "Outer Islands"; see H. J. de Graaf, Geschiedenis van Indonesie (The Hague (Bandung: van Hoeve, 1949), p. 430. 
English were allowed to trade in the "outer islands" where Dutch political control was virtually absent.

The fact that G. P. King, the Lombok merchant, was an Englishman, combined with the increasing trade to Singapore, was enough to make the authorities in Batavia and The Hague believe that the next step would be the annexation of Lombok by the English. ${ }^{55}$ Although at the outset the Minister of Colonies, J. van den Bosch, and Staatsraad J. C. Baud considered it wiser to let commerce develop naturally, this time it was King Willem I who became nervous. Rumors had reached him in 1836 that the English were already taking possession of Bali to build a second Singapore. ${ }^{56}$ The fear that the English could easily find an excuse to control the Lombok trade by way of a settlement at Ampenan brought the authorities in The Hague into action.

The mid-nineteenth century colonial adventure of the Dutch in Bali started in 1836 with a policy of expansion, based on clear economic considerations. It ended in 1849 with the meager result that Dutch "honor and dignity" were not too badly damaged. Mads Lange played an important role in this episode as a channel of information and as a buffer between the Dutch and the Balinese.

\section{The NHM Failure}

Lombok's increasing trade with Singapore made Batavia believe that the English were intending to obtain control over the rice trade in the archipelago. Dutch authorities also feared that, instead of Batavia, Ampenan would become a center for the A us tralia-Bengal trade. ${ }^{57}$

At the end of 1837 it was decided in The Hague that the Nederlandsche Handels Maatschappij (NHM--Dutch Trading Company) was to function as a political outpost on Bali and Lombok to conceal a Dutch diplomatic offensive. The aim was to obtain contracts which bound the rajas to Batavia.

Though Lombok had been the main target, it appeared impossible for the NHM to settle on that island. King's position proved too strong, especially after he had gained the monopoly of the rice trade. Therefore, from August 1839 till June 1844 the NHM maintained its agency in Kuta. ${ }^{58}$

The results were disastrous. Whereas in the same port Lange was making good profits, the NHM accumulated losses amounting to 180,000 guilders, which, after a furious quarrel between the NHM and Batavia, had to be paid by the latter. Because the Trading Company was not allowed to sell opium and weapons, ${ }^{59}$ and

55. ARA, MvK V July 14,1836 no. 6; V November 11,1836 no. 2.

56. ARA, MvK V November 11,1836 no. 2; V November 18, 1836 no. 16. J. C. Baud was at that time the king's most important adviser on colonial affairs. In 1840 he succeeded van den Bosch as Minister of Colonies.

57. ARA, MvK V November 25, 1836 no. 6/632.

58. The NHM agency at Kuta was established just before the arrival of Mads Lange. On the NHM agency, see Lekkerkerker, "Voorspel," pp. 198-322, and, among others, ARA, MvK V January 5, 1846 no. 4 geh.

59. The NHM was not allowed to sell weapons because this was obviously against the political interests of Batavia. From 1827 till 1833 the NHM had the monopoly on the sale of opium, but this did not work, because of its lack of experience in dealing with opium and because there was too much smuggling. Therefore in 1833 Batavia reintroduced the system of farming out its sale. 


\section{Bali}

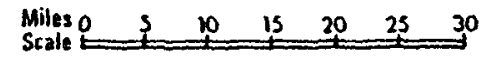

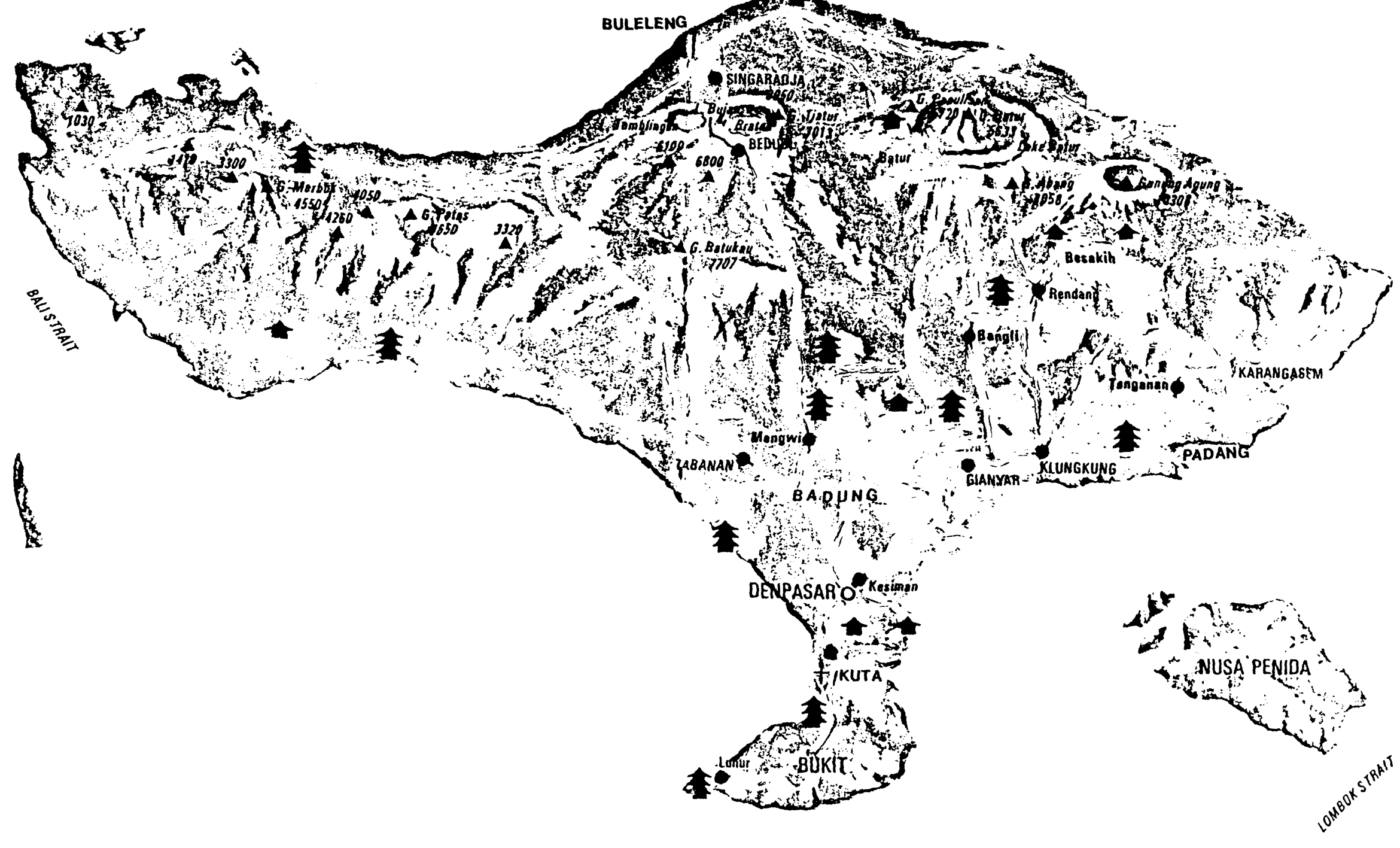


because it had no cheap kèpèng available, the idea of the NHM being a useful instrument of Dutch policy on Bali was a complete failure: no access to trade, no political achievements.

\section{Batavia's Contracts}

The main colonial objective still had to be achieved, namely, a contract which excluded any possible English interference with the islands. To that end, Batavia started its own offensive. From 1840 till 1843 Commissioner J. H. Huskus Koopman was sent five times to Bali and Lombok. ${ }^{60}$ His main task was to gain a victory on paper: the rajas had to acknowledge Dutch "sovereignty" over their territories--whatever that word may have meant to nineteenth century Balinese-and they had to forbid the looting of wrecked ships on their shores, the so-called tawang karang. ${ }^{61}$

Commissioner Huskus Koopman entered a Balinese political arena where there were already, roughly speaking, four main parties:

1) Buleleng-Karangasem in the north and east of Bali; hostile to Badung and Mataram; later on the main target of Dutch expeditions.

2) Klungkung, Gianyar, Mengwi in South Bali; between neutrality and a proBuleleng-Karangasem attitude.

3) Mataram on Lombok; hostile to Buleleng-Karangasem; in the 1830s prime target of the Dutch, in the 1840s "allied" with Batavia; mediation by G. P. King.

4) Badung and Tabanan in South Bali; hostile to Buleleng-Karangasem; more or less neutral towards Mataram and on strained terms with Klungkung and Mengwi; "allied" with the Dutch; mediation by Mads Lange.

A fifth party was formed by the inland "kingdom" of Bangli, which was hostile to all its neighbors, and which eventually became "allied" with the Dutch by way of Badung.

This constellation of Balinese political relations dominated the course of events during the 1840 s.

\section{Badung}

Huskus Koopman's first trip to Bali did not leave him very optimistic. "Everything here is pretense," he wrote, "nothing is certain, the greatest contradictions collide here daily." ${ }^{62}$ Patience was a quality Huskus Koopman learned to practice in Bali.

His first success was accomplished on his second trip. Raja Kesiman signed a treaty in which he recognized his territory as being under Dutch "sovereignty." 63

60. For an outline of the activities of H. J. Huskus Koopman, see Ikhtisar keadaan politik Hindia Belanda tahun 1839-1848 (Jakarta: ANRI, 1973), pp. 434-99.

61. Especially after 1840 the tawang karang issue became important. Because of the increasing sugar cultivation in East Java, many ships with sugar cargoes for Holland went along the south coast of Java, through the Bali strait, on their way to Europe. Fasseur, "Koloniale paradox," p. 175, n. 57.

62. Report June 30, 1840, "La M," Secret Report, August 5, 1840, "La K3," ANRI .

63. The complete treaties are in Surat-Surat Perdjandian antara keradjaan-kera- 
Thanks to the shipwreck of a Dutch vessel, the Overijssel, on the Badung shores at that time, followed by its looting by the local population, the envoy could threaten the raja with Batavia's revenge if Kesiman did not show his goodwill. A second reason for the raja signing may have been the growing tension between his area and nearby Klungkung. With Batavia's backing he felt stronger in the South Balinese political arena.

Though Lange's precise role in this case is not altogether clear, his influence must have been important. Raja Kesiman hesitated continually before he signed the treaties and Huskus Koopman needed to apply a lot of pressure, and enlist Lange's help to obtain a second treaty in 1842, this time on the tawang karang issue. ${ }^{64}$ One evening when a depressed Huskus Koopman was about to leave Badung after waiting for more than a month for the raja's signature, Mads Lange came on board the commissioner's ship just before the anchor was raised. He had the treaty in his hand, signed by raja Kesiman. ${ }^{65}$ What had actually happened is not known, but Mads Lange had arranged it at the very last moment. Probably the Danish trader had urged his raja to sign and had offered to be responsible for the treaty's observance.

\section{Buleleng-Karangasem-Klungkung}

In 1841 and 1843 the rajas of Buleleng, Karangasem, and Klungkung had other reasons for signing similar treaties with the Dutch. They were all hostile to--and wary of--the Mataram raja since he had gained hegemony over Lombok. This Mataram raja no longer recognized the Dewa Agung of Klungkung as the highest authority among the Balinese rajas, and the rajas of Buleleng and Karangasem wanted to exercise more control over Lombok by replacing the Mataram raja, with whom they had only a distant kinship relation, by a closer relative. Huskus Koopman knew about these conflicts and promised the rajas Dutch military assistance against Lombok in exchange for their signing the treaties.

It is my view that this policy of Commissioner Huskus Koopman caused later misunderstandings and conflicts between Buleleng-Karangasem and Batavia. First, the commissioner was not allowed to promise any military assistance because Batavia still wanted a cheap, diplomatic solution, not an expensive military one. Second, the treaties were in Malay and Dutch, not in Balinese, so that the rajas may very well have misunderstood their exact substance. There is some evidence that they regarded the contracts as friendship treaties without further political consequences. ${ }^{66}$

djaan Bali-Lombok dengan pemerintah Hindia Belanda $1841 \mathrm{~s} / d 1938$ (Jakarta: ANRI, 1964).

64. The shipwreck of the Overijssel in July 1841 caused a fuss in Holland when its captain, Govert Blom, published his story that same year (see n. 51). Almost immediately Minister J. C. Baud ordered the Governor-General to include the tawang karang issue in existing and future treaties. See /khtisar keadaan, pp. 440- 44 .

65. Report H. J. Huskus Koopman February 19, 1842 no. 44/25, Secret Report, July 18, 1843 "La B2," ANRI.

66. Ikhtisar keadaan, p. 436; Surat-Surat Perdjandjian, pp. 1-13, 77-87, 102-12; van Hoëvell, Reis, 3, p. 47 . 
Lombok

In the case of Lombok, George King, the personification of the "English danger," played a crucial role as political mediator. He stood between his Mataram raja and the Dutch envoy, who could do nothing without his mediation. More clearly than Lange, King acted as a translator between two political languages and estimated the proper, practical value of the treaties. He did not want any trouble with Batavia, which might have endangered his trade, and Huskus Koopman had set himself during his fourth and fifth trips in 1843 just one goal: a contract, no matter how!

King and his raja, Gusti Ngurah Ktut Karangasem, must have gauged the political climate very well: there were hostile parties on Bali who were ready to receive Dutch military assistance against Mataram; and from Huskus Koopman King knew Batavia's aims and the practical value of a signed piece of paper. Besides that, for Mataram too there was the potential usefulness in Balinese politics of having a distant ally in Batavia.

Eventually, in June 1843, Huskus Koopman obtained a signed contract from the Mataram raja. Two years earlier, Minister Baud had still been pleading for a military expedition against Lombok to avert the imminent English danger, but now, ironically, thanks to Englishman King, such action proved unnecessary. ${ }^{67}$

\section{Balinese and Dutch Political Purposes}

Huskus Koopman, the Dutch envoy, had to provide a bridge between two political worlds: on the one hand the European world, in which the juridical and written treaty was an important concept and Dutch-English relations were the main element; on the other, the Balinese world with its accent on relative and continually changing balances of power, power, moreover, which had to be present and visible in the shape of strong persons, wealth, and the ceremonial display of status, ${ }^{68}$ not distant and abstract. For the Balinese, local power struggles were the main interest. These two traditions had hardly any points of contact with each other.

Lange and King were the links between the two worlds, and two Balinese parties, Badung and Mataram, exploited these links for their own political advantage. King had clearly acted as a political mediator. Lange's role was less apparent, but, thanks to him, treaties were signed and his raja could maintain friendly relations with Batavia.

At the end of 1843 all the contracts Batavia and The Hague wanted were signed. The imaginary diplomatic war against the English was won, but the real trouble with Bali had just begun.

Dutch Interference and Balinese Politics $I I$ : The Military Offensive and the Mads Lange Connection

The moment the NHM agency left Bali, Lange appeared to be the cheapest "channel" through which Batavia could keep an eye on Balinese affairs. Huskus Koopman recommended the Dane warmly as an ideal agent for the Dutch, because he had inconspicuous access to information and enjoyed great confidence among rajas in South Bali. On May 1, 1844, Batavia appointed Lange as the Dutch Agent

67. Ikhtisar keadaan, pp. 449-54; ARA, MvK V January 29, 1842 no. 43 geh.

68. On the spectacle and theater in Balinese politics, see Geertz, Negara. 
on Bali, and so he became the official middleman between the Dutch colonial government and the Balinese. ${ }^{69}$

The dining-room in his factory was already established as an informal meeting place between foreigners and Balinese. According to Helms, "cosmopolitan parties" were often held. ${ }^{70}$ The European participants were foreign traders, early "tourists," like W. R. van Hoëvell and the botanist $H$. Zollinger, the linguist $R$. Th. Friederich, who did most of his "fieldwork" in Lange's factory, and, after 1845, Dutch soldiers and the new Commissioner for Bali, Resident I. F. T. Mayor of Besuki. Frequent Balinese guests included the rajas of Tabanan and Badung. In particular raja Kesiman, "with long flowing hair, tall, erect and portly," and his golden payung, was a favorite guest because of the splendid stories he told. ${ }^{71}$

The Lange factory near Kuta became a place where the two worlds could get used to each other, a kind of political free port. In this atmosphere raja Kesiman could get acquainted with Dutch politics, so that he could use them for his own aims in South Bali. Mads Lange was an indispensible link in this relationship. Besides being one of Kesiman's advisors, he also acted as his protector in case of conflicts between Kesiman and the Dutch. Each case of conflict concerned shipwrecks on the Badung shores, followed by looting, which was against the treaty Lange solved all these small crises, probably paying the damages out of his own pocket.

\section{The Conflict}

On the other side of the island, there was no European to act as a mediator, and on the Buleleng and Karangasem shores several cases of tawang karang, or ship-looting, also occurred. When in 1845 the recently appointed Commissioner of Bali, Resident Mayor, went to Buleleng to investigate these cases and exchange the contracts (which had finally been ratified by Batavia), he met a hostile reception. The raja of Buleleng and his patih, Gusti Ktut Jelantik, denied the existence of a contract, and "friendly relations" was their maximum offer. Moreover, at some distance from the raja's palace, the Resident was forced to leave his litter and walk the last meters; to make matters worse, his chair was much lower than that of the raja. Mayor regarded this treatment as an "affront." 72 He advised Batavia that it had to interfere because "the government should not submit to the fact that contracts, once made, are being broken at random." 73

In Batavia, the newly arrived--and highhanded--Governor-General J. J . Rochussen also wanted a firmer policy towards Bali. Instead of treaty diplomacy, he thought in terms of a punitive expedition. Moreover, according to Rochussen, Gusti Ktut Jelantik had insulted "Dutch honor," for the patih of Buleleng had

69. Ikhtisar keadaan, p. 455. Geertz (Negara, p. 205) is mistaken when he mentions the function of commercial agent, which Lange definitely was not.

70. Helms, Pioneering, pp. 44-45.

71. Ibid. Raja Kesiman could speak a bit of Malay, but probably most of the "stories" were translated from Balinese into Malay, by, for instance, a follower/ interpreter of raja Kesiman named Gusti Wangaya. Mads Lange himself must have spoken Balinese, but I am not sure whether he could read or write it.

72. Report I, F. T. Mayor, May 30, 1845, Secret Report, July 14, 1845, "La B 2," ANRI. See also K., "Een Bezoek," pp. 213-26. Resident Mayor was a respected civil servant who had earlier been Governor of Makasar and Resident of Solo.

73. Report Mayor, see n. 72 . 
spat his sirih on a Dutch sea pass. This occurred after a ship had been looted on the Karangasem shores and the captain had tried in vain to rescue his cargo. "Such scorn has to be avenged, for, if not, our authority in the Indies is gone," Rochussen wrote to Minister Baud. ${ }^{74}$

In May 1845, when Lange, in his capacity as Dutch Agent on Bali, tried to settle the looting of another ship on the Karangasem shore, it was the same Gusti Ktut Jelantik, who stated that, because the government was already planning war against Buleleng, this case had to be solved by means of the keris. ${ }^{75}$ Now both parties were preparing war.

Apart from the growing Dutch-Buleleng conflict, two Balinese parties had formed on the basis of old antagonisms: Badung, led by raja Kesiman, against Buleleng, led by Gusti Ktut Jelantik. Each man faced a strong opponent.

\section{The Lange-Mayor Correspondence}

The correspondence between the Dutch Agent on Bali, Mads Lange, and I. F. T . Mayor, Resident of Besuki and Commissioner for Bali and Lombok, reveals the political aspect of the Lange connection: how he was used by Mayor and, to an even greater extent, by raja Kesiman, in attempts by each of them to manipulate the other. ${ }^{76}$ Lange stood between his raja and the Dutch Resident. He made it possible for each side to contact the other, because he was loyal to both of them. The reasons for his commitment to his raja are clear. With respect to Mayor, personal friendship and the conviction that Kesiman needed the Dutch made him loyal to the Resident. In fact Lange saw his function as Dutch Agent more as a personal relationship with Mayor, than as an official one. When Mayor had asked Lange to send his bill of expenses, the Dane answered: ". . . but first (I) wishes to know if you pay that or Government, for in the first case, I send noon at all, and in the second case I send a large one." 77

Through Lange, Mayor knew the extent to which he could rely on his South Balinese "ally." Though he knew that Lange depended too much upon Kesiman, Mayor took all his information seriously. It was all the information there was.

On the other hand, Kesiman could use his Danish perbekel/shahbandar in a more indirect and subtle way. Through Lange, raja Kesiman assured himself of possible Dutch backing in order to play his own Balinese political game, the aim of which was control over South Bali and the defeat of his northern opponent Gusti Ktut Jelantik. By way of Lange's letters and reports, Kesiman continually urged Resident Mayor to attack Buleleng.

74. Letter G.-G. Rochussen to Minister Baud January 1, 1846, ARA, Semiofficial corr. G.G.-MvK. January 1, 1846 no. 42. See also Fasseur, "Koloniale paradox," p. 175. In the same letter Rochussen considers the Balinese rice surplus a good reason for annexation because Java was having to cope with increasing rice shortages.

75. Ikhtisar keadaan, p. 465.

76. This correspondence, found in Malang, East Java, is in the possession of Drs. J. B. A. F. Mayor Polak, the great-grandson of Resident Mayor. It was rescued from the Residency archive of Singaraja (North Bali) just before the Japanese invasion. I am very grateful to Drs. J. B. A. F. Mayor Polak for allowing me to use this material. Photocopies of it are now available at the KITLV in Leiden.

77. Correspondence, Lange to Mayor August 5, 1846. Lange's English was not perfect. 
The First Expedition: 1846

In February 1846 Batavia decided to send a military expedition against Buleleng, to "punish" Gusti Ktut Jelantik and his raja for their "disobedience" to the colonial government.

During the preparations, by way of Lange, raja Kesiman offered his help to the Dutch in exchange for the colonial assurance of protection against a possible attack by Buleleng. And once this assurance was given, the raja repeatedly expressed his regret that it took so long before the expedition started. ${ }^{78}$

The first military expedition against Buleleng took place at the end of June 1846. The royal palace at Singaraja was destroyed and within a few days new contracts were signed which confirmed the earlier ones. This time it was King who organized the treaties' signing. He offered to mediate between Resident Mayor and the temporarily defeated raja, for, as he wrote, "in my opinion it will be rather difficult for the Rajah to understand the exact meaning of the contracts from the number of European names used to which he is a perfect stranger and which cannot be conveyed in their language." 79 After all, King already had some experience with the Lombok treaties of 1843, and, in this instance, his position was more "neutral" than Lange's, because Lange was considered to be a pro-Dutch follower of raja Kesiman.

\section{7: Confusion}

The aftermath of the operation, however, caused even greater conflicts. "What to do with Bali?" was a question nobody could answer. A difference of opinion, not to say a serious quarrel, arose between the experienced Resident Mayor and the Governor-General. ${ }^{80}$ In the eyes of Rochussen, the Bali problem was solved, but, according to Mayor, nothing had been achieved yet, and he was right. Dutch policy was somewhere between a punitive action and the annexation of Buleleng, for the raja had to pay 400,000 guilders and a Dutch garrison was stationed at Buleleng.

The Balinese reality was that the war had just started. Only two months after the expedition, in September 1846, a new flow of letters from Lange reached Mayor, urging further military intervention in North Bali. ${ }^{81}$ Political tension in Bali increased, with Gusti Ktut Jelantik and raja Kesiman the main ontagonists. The outcome depended upon the more or less neutral rajas--and upon further Dutch intervention.

In my opinion, the Lange-Mayor correspondence also reveals that Mads Lange had no clear perception of the delicate relationships among the Balinese. His ideas on Balinese politics, as they emerge from his letters, are in fact rather puzzling. Though he must have known a lot about a wide variety of specific relationships, it seems likely that he had no overall perception of the Balinese political constellation. He remained an outsider in local politics. His main idea was probably that his raja might lose, and, through this, that his own trade might be threatened. For in-

78. The assurance was given in Report, May 6, 1846; Corr. Lt. ter Zee Sluyters to Mayor May 23, 1846.

79. Corr. King to Mayor July 7, 1846. The contracts were signed on July 9, and this time they were in Dutch, Malay, and Balinese; Surat-Surat Perdjandjian, pp. 87-97, 106-12.

80. Corr. Mayor to Batavia July-September 1846.

81. Corr.; this continued till the beginning of 1848, when Resident Mayor died. 
stance, when, in November 1846, Kesiman visited the Dewa Agung of Klungkung, who had now become part of the anti-Dutch Buleleng-Karangasem party, Lange wrote to Mayor:

Now the last plea of the Dewa Agong is he wants the Old Rajah of Casseman to come to Kalungkung, for to kill him . . . for no other purpose . . . the old man wants to go, he says, he is deaf. . . . now Casseman is in a ship with Dewa Agong, we [Mayor and Lange] must stand or die together! ${ }^{82}$

However, raja Kesiman returned alive and continued his own political game.

Another example of Lange's rather poor analysis of Balinese relations, and of the way his letters eventually influenced Batavia, is his advice on an administrative division of Bali that would follow a successful second expedition. He thought three rajas would be enough. Raja Kesiman should govern the south, Tabanan the west, and Bangli the east, including Klungkung. ${ }^{83}$ This was almost the same plan that the generals Jhr. C. van der Wijck and A. V. Michiels brought on the second and third expeditions. In terms of practical Balinese politics, however, this proposal was totally unrealistic. Such a degree of centralization could not be applied to $B$ ali at that time, apart from the fact that it ran contrary to the whole complex history of feuds among the Balinese elite, which would be impossible to control with the authority of only three rajas.

At the same time, Lange also suggested that in case of a second expedition an at tack should be launched on Klungkung and Karangasem via the southern harbor of Padang. ${ }^{84}$ This advice was to bring serious trouble to the Dutch army during the third expedition in 1849. But before that an even more damaging Dutch defeat occurred in 1848.

The Dutch Defeat: 1848

Raja Kesiman had to wait two years for another Dutch expedition. This second intervention was caused by Batavia's sense of honor, which could not tolerate being ignored any longer by the still independent Buleleng, led by Gusti Ktut Jelantik, who appeared quite unwilling to bow before the Dutch.

It was a short and disastrous expedition. ${ }^{85}$ In June 1848 the Dutch troops were shattered at Jagaraga, the inland fortress of the Balinese in Buleleng. Governor-General Rochussen did not dare to send extra troops because of the expected political unrest in Java as a consequence of the revolutions in Europe. So, for the time being, the only results were damage to Dutch prestige, a still independent Buleleng, and a much more cautious raja Kesiman.

The "Final" Settlement: 1849

The 1848 defeat gave the Dutch a severe shock and "the Balinese" became the "nightmare" of the mid-nineteenth century Dutch colonial state. There was no

82. Corr. Lange to Mayor November 22, 1846.

83. Corr. Lange to Mayor April 16, 1847. The Dutch did not want direct colonial rule in Bali, only indirect control by way of "loyal rajas."

84. Ibid.

85. On the second expedition, ARA, MvK November 7,1848 no. 16; coll. A. H. W. de Kock no. 1; J. van Swieten, Krijgsbedrijven tegen het eiland Balie in 1848 (Amsterdam: Doorman, 1849). 
alternative but to show the Balinese, the English, and the archipelago that the defeat was just a mistake, and that the Dutch were still the dominant power in the Indies.

Already in the summer of 1848 Batavia was making preparations for a revengeful and final settlement of the Bali problem. The blockade of Bali, declared prior to the second expedition, was continued. Extra troops arrived from Holland. The elderly General A. V. Michiels, the man who had "won" the Padri War, was given military and political leadership of the operation. Twelve thousand men were shipped from Java to Bali in April 1849, in one of the largest Dutch military expeditions ever organized in the archipelago. ${ }^{86}$

Although the military goal of the expedition was clear--revenge and punishment--its political objectives were not. Batavia still did not want direct rule over Bali, and even would have liked to avoid further interference in Balinese affairs. So, Batavia's goal was a "lasting settlement of the war in a way which was in accordance with the dignity of the Government," or, to put it in other words, a victorious withdrawal.

This time the Dutch were successful. In April 1849, Buleleng and the fortress Jagaraga were conquered. Then, in May, Karangasem was subjugated, a feat accomplished through an alliance with troops offered by the raja of Mataram. In fact, it was Mataram that conquered Karangasem and killed the Balinese leader, Gusti K tut Jelantik. In a winning mood, the Dutch started on the last phase of the operation: the punishment of the Dewa Agung of Klungkung. For this they shipped a large portion of their troops to Padang on the southeast coast, so that for the first time Dutch forces entered the South Balinese political arena.

Suddenly the situation changed completely. During an unexpected night attack by Balinese from Klungkung at Kusamba (between Padang and Klungkung) on May 24 , General Michiels was wounded, and he died the next day. ${ }^{87}$ At the same time health conditions quickly deteriorated among soldiers and coolies because of widespread dysentery. The Dutch troops had to withdraw temporarily and wait for reinforcements and a new commander-in-chief. In the meantime, the Dutch no longer had any decisive influence on the outcome of the events. The South Balinese, and especially raja Kesiman, organized the settlement of their own conflicts; the Dutch knew hardly anything about it. And it was Mads Lange who, by accident, was to play the crucial role of buffer between "Dutch honor" and Balinese politics.

\section{Lange as a Buffer}

The last days of May and the beginning of June 1949 formed a period of great confusion for all parties in South Bali, for nobody knew exactly what the other side was doing and what, after all, the outcome would be.

Things also began to look dark at the Lange factory at Kuta at the end of May. According to Helms:

86. On the third expedition, see ARA, MvK V April 16, 1850 no. $188 / \mathrm{k}$ geh.; August W. P. Weitzel, De derde militaire expeditie naar het eiland Bali in 1849 (Gorinchem: Noorduyn, 1859) ; J. O. H. Arntzenius, De derde Balische expeditie in herinnering gebracht (The Hague: Belinfante, 1874).

87. Ibid., and C. van der Hart, "Herinneringen van Bali in 1849," De Gids, 2 (1854), pp. 642-56; H. C. Klinkert, "De laatste strijd en heldendood van Generaal IMichiels ," TN/ (1870), 2, pp. 187-215. 
. . all these events not only seriously interfered with our business, but made our position at Badung exceedingly uncomfortable. . . . Our Rajah, the Old Kassiman, had engaged with the Dutch to conquer the neighbouring state, Mengoi [i.e., Mengwi], but failed, and his men were seriously beaten. This raised excitement around us to a great pitch, for a counter attack was expected every moment. Our position became precarious, for our factory, full of plunder, was much coveted by the enemy, and an attack was actually threatened. ${ }^{88}$

While tension in South Bali increased, through the mediation of the patih of Mataram it was agreed to have a meeting on June 10 of all parties involved: the Dutch, Badung and Tabanan, and Klungkung, together with Mengwi and Gianyar. Probably this meeting was intended to settle the conflicts as quickly as possible. For at that moment the Dutch were still in a weak position and the Balinese might have been able to solve the problem among themselves without too much Dutch involvement. However, at the last moment Klungkung did not want to give up the fight. The Dutch received a peremptory letter telling them to ask for pardon for the way they had insulted the Dewa Agung. This letter made the Dutch decide to attack Klungkung, and, gathering together their final strength, they advanced on the court-capital of the Dewa Agung on June 10, the day of the meeting.

Confusion and panic reached a climax on that day, because none of the Balinese knew that the Dutch were planning to attack Klungkung, whereas the Dutch thought that the meeting had been canceled. Due to the fact that both Klungkung and the Dutch lacked any regulated contact a dangerous situation developed. In this respect it is striking that the Dutch made hardly any use of their agent, Mads Lange. Even Lange knew nothing of the Dutch attack on Klungkung. Nevertheless, it was Lange who, on his own initiative, was to rescue the Dutch.

Because the rajas of Badung, Tabanan, and Gianyar still thought that the meeting scheduled for June 10 would take place--they also did not know anything about the Dutch attack--they arrived in Klungkung on the 9th with 20,000 men. As usual, the important nobles brought large followings, for status, or, should things go wrong, to protect either their individual or collective interests by force of arms. The Dutch in their turn did not know that in total about 33,000 Balinese troops were assembled at the residence of the Dewa Agung at that moment. A fight might have developed into a complete massacre and probably a definitive Dutch defeat.

To make things even more complex, there is reason to believe that raja Kesiman wanted to seize the opportunity of the meeting to complete his political game: final control over South Bali by way of a silent--or halus--coup through assertion of his leadership. In order to achieve this aim he had brought 16,000 men to Klungkung, and he needed a distant Dutch presence, but not an attack. Therefore his scenario was rudely destroyed by the advancing Dutch troops.

Mads Lange, who was on his way to Klungkung on June 10, suddenly heard the sound of gunfire. When he arrived in Klungkung, he encountered a scene of total chaos. The Dewa Agung and his followers were making preparations for a puputan, and raja Kesiman was very afraid that, in the event of a Dutch attack, he would lose control over his men and they would oppose his European "allies" also. If that occurred Kesiman's political game would vanish in the smoke of battle.

88. Helms, Pioneering, p. 68. Raja Kesiman had two reasons to attack Mengwi. First, to stop Mengwi from supporting Klungkung against the Dutch, and, second, because for a long time there had been a local feud between Badung and Mengwi. Nordholt, "Macht, mensen en middelen," pp. 124-27. The same coherence between support for the Dutch and the settlement of local antagonisms made the raja of Mataram decide to conquer Karangasem-Bali. 
Mads Lange did not hesitate a moment. Immediately he rode to meet the Dutch troops who were already very close to Klungkung. He stopped them. By accident Lange stood as a human buffer between the forces, and so prevented a dreadful encounter. The ultimate and bloody climax was not reached.

From that moment on, the situation again changed, but now to the advantage of raja Kesiman and, on another level, to that of the Dutch. Raja Kesiman was now able to complete his coup and he took it upon himself to represent the Dewa Agung, and speak on behalf of "South Bali." Finally, and thanks to Mads Lange, he was the winner in the Balinese conflict. On the other hand, the Dutch were not again defeated, but retained their honor. The Dewa Agung of Klungkung finally surrendered to raja Kesiman and it was now possible for the Dutch to withdraw "with dignity."

\section{The Kuta Peace}

Shortly after these dramatic events new Dutch troops and a new commanderin-chief arrived. This commander was Duke Bernhard von Saksen Weimar, a nobleman, and his task was to perform a purely ceremonial role during the ritual termination of the Dutch-Balinese conflict. ${ }^{89}$ For, instead of resulting in a massacre, the third expedition reached its climax at a ceremonial meeting between the southern rajas and the Dutch on July 15. This meeting took place in the Lange factory near Kuta and was attended by about 30,000 followers of the rajas.

At this meeting several events took place concurrently. First was the upacara (ceremony) in honor of raja Kesiman, the Balinese winner, who acted as the South Balinese leader, and had now temporarily subdued the Dewa Agung, while his trader had been able to keep the Dutch away. Second, the meeting was a glorious moment for the Dutch because, in their eyes, all the South Balinese rajas had submitted to Dutch "sovereignty" over Bali. Now the Dutch could depict the third Balinese expedition back home as an undeniable victory. At last they had got rid of that whole damned Bali. Doubtless the South Balinese rajas thought the same about the Dutch, and were also justified in considering the outcome a victory, for the Dutch were leaving their territory and would not return for another fifty years. So, the South Balinese negara retained their independence for the rest of the nineteenth century.

The contracts signed with great ceremony at the meeting in Lange's factory were not intended to contain any article which might lead to further Dutch interference. As long as the Balinese rajas recognized formal Dutch sovereignty over their territories, the Dutch promised not to interfere in their affairs. The treaties were basically the same as those sought by Minister J. C. Baud ten years before. ${ }^{90}$ Were the English finally defeated?

89. See n. 86, and D. J. Koff, "Hertog Bernhard van Saksen Weimar en de slotscène der Bali expeditie," Insulinde, 38/42 (1898). It was Mads Lange who arranged, after the arrival of the new commander, a short meeting with the South Balinese rajas, who were curious and pleased to meet, at last, a European equal.

90. For the contracts, see Surat-Surat Perdjandjian, pp. 21-24, 153-60, 197-204, 219-26. During these years there was no sign of any English interference. Though the raja of Buleleng had asked for British help in 1847, the answer was negative; see N. Tarling, "British Policy in the Malay Peninsula and Archipelago 1824-71," JMBRAS, 30, 3 (1957), p. 147. Another Balinese winner in 1849 was the raja of Mataram. In gratitude for his support the Dutch granted him control over Karangasem-Bali, which Mataram retained till 1894. 
The fact that the meeting was held at the factory near Kuta symbolized the role of Lange as a mediator. Though his appearance as a human buffer on June 19, 1849 between the two confused but desperate parties had been rather accidental, it was nevertheless a crucial turning point in the Dutch-Balinese encounter. Therefore the encounter's subsequent termination could take place in his factory. Mads Lange had rescued his raja Kesiman from imminent downfall, and this raja immediately used Lange for staging the "closing ceremony" at the factory, which was attended by thousands of Balinese and which enabled raja Kesiman to show his superiority over the other South Balinese lords. Mads Lange received from raja Kesiman the honorific title of punggawa besar, ${ }^{91}$ one of the highest titles/functions in the Balinese state, but it was also Mads Lange who had himself to pay all the expenses of the meeting at his factory, and this must have cost him a fortune.

At first sight the ceremonial meeting at the Lange factory in July 1849 evokes the image of the theatre state as put forward by Clifford Geertz. ${ }^{92}$ Indeed spectacle and court ceremonial formed an important part of Balinese politics. Looking at these Balinese politics during the $1840 \mathrm{~s}$, however, it is my conviction that theater was in no way the sole substance of the Balinese state. For, the Dutch had not been fighting "theatre states," but negara where power embraced far more than the ritual enactments of status. A strong Balinese raja was no mere ritual object, or "icon, a figuration of the sacred in itself sacred." 93 Raja Kesiman, for instance, apart from other attributes, was also a politically powerful man who eventually controlled his own environment-- and even all of South Bali, though for a short period-with every means at his disposal, spectacle included. The pomp of the ceremony at the meeting in Lange's factory was the visible part of Kesiman's power at that moment, but not its substance.

\section{Lange's Last Years}

Mads Lange had not only been an important agent of the Dutch, he had also served as an indispensable part of the power of his raja. As a merchant and a commercial broker, who perfectly understood the social atmosphere in which he had to act, he provided his protector, Kesiman, with crucial trade contacts, which made Kuta, and, through it the "kingdom" of Badung, a prosperous place. On the basis of the sea trade, raja Kesiman had been able to dominate the South Balinese political arena, because neighboring areas like Tabanan, Mengwi, Gianyar, and Klungkung were to a large degree dependent on the activities of Kesiman's shahbandar, Mads Lange. It is, I think, not correct to conclude that foreign trade served only as an insulated "source of tribute, of luxuries to decorate the theater state," nor that Kuta spread "the Spirit of Commerce throughout the whole of southern Bali," making Balinese lords "mercantile." 94 Because Balinese lords had themselves been mercantile (one might even say, merchants) for a long time, Mads Lange could settle down near Kuta, and give them what they most needed: contacts with the sea trade.

Nevertheless, Badung's power and Lange's prosperity did not last forever. Already after 1848 Lange's trade had begun to decline. Ships stayed away because of the Dutch blockade of the island (1848-49) and several severe losses did not

91. See raja Kesiman's letter to Lange, shortly after the Kuta meeting, in van Naerssen et al., Catalogue, p. 151.

92. For a definition of the "theatre state," see Geertz, Negara, p. 13.

93. Ibid., p. 108.

94. Ibid., pp. $92,96$. 
improve his financial position. Not only did the 1849 upacara cost him a lot of money, but the preceding years of warfare had also not favored his trading activities. ${ }^{95}$

The situation soon worsened. The rice-producing hinterland had suffered from the insecurities of the war, with exports almost ceasing and disease widespread. In 1850 smallpox paralyzed social and political life in Badung, and several employees of the factory died. ${ }^{96}$ Shortage of water, epidemics, and plagues of rats damaged the prosperity that had previously existed there. Lange even had to import rice from Lombok for his raja, and a newly bought machine for the production of coconut oil was unusable. ${ }^{97}$ Raja Kesiman was also drawn into new conflicts with other neighboring rajas. South Balinese competitive politics including small-scale wars continued until the next Dutch expeditions in 1906-8.

Badung became a poor area unable to recover from its setbacks. Whereas Lombok continued to export rice on the route Australia-Singapore-China, trade in $\mathrm{Ba}$ dung almost ceased. ${ }^{98}$

Two major reasons may be given for the permanent decline of the Kuta trade after 1850. First was the increase in the number of steamships in the inter-Asiatic trade. The harbors of Kuta offered insufficient accommodation for these larger ships, whereas Ampenan was more suitable. Second, soon after 1850 the Dutch colonial government settled down in Buleleng, and from that time on the harbor of Pabeyan Buleleng began to attract most Balinese exports and the larger part of the interinsular trade. Moreover, Buleleng also became a center of the Balinese opium trade. So Kuta was bypassed by modern technology and the competition from a new commercial rival in northern Bali.

Mads Lange was not able to withstand these changes. In May 1856, just before he was to leave Bali for Denmark, he died, probably poisoned by a vengeful member of a competing royal descent group in Badung. ${ }^{99}$ His brother Hans and his nephew Peter Christian tried unsuccessfully to continue the factory. When in 1863 raja Kesiman died, the factory was no longer protected. Peter Christian was the only member of the Lange family who survived. He went back to Denmark, also in 1863 , and, except for the stone walls, nothing remained of the once prosperous factory. ${ }^{100}$

Looking back over Lange's role in Bali, it is clear that he acted on several levels as a middleman between Bali and the outside world. By virtue of his personal qualities he was able to fit into an existing structure, in which occasional foreigners could be tolerated. He was a broker in the trading field where he felt at

95. Helms, Pioneering, p. 70; Correspondence, Lange to AR Banyuwangi July 7, 1855, "I have lost a great deal of money by the war in Bali."

96. Corr. Lange to AR Banyuwangi January 23, 1850; November 13, 1850 . In Badung the smallpox resulted in about 4,000 deaths in one year.

97. See P. L. van Bloemen Waanders, "Dagverhaal eener reis over Bali in juni en juli 1856," TNI (1870), 1, pp. 415-41, p. 429.

98. On the Lombok trade, see report, J. H. Peter, 1856, ARA, NHM; J. P. Freyss, "De bevordering van welvaart in den Indischen archipel buiten Java," TNI (1860), 1, pp. 65-91, pp. 74, 86. George P. King left Ampenan in 1850 and went to Kutai (Kalimantan) where he lived until about 1860.

99. Nielsen, Leven en avonturen, p. 212. Hans Lange died a few years later. 100. Ibid., p. 197; Corr. Peter Chr. Lange to AR Banyuwangi September 19, 1863. 
home. He was a channel of information for the Dutch and the Balinese, whose different political purposes accidentally encountered each other. He was a mediating buffer at crucial moments, because in that way he could protect his friends and also the system--of separation but connection--which gave him a place and a career at Kuta. Lange did not become a second raja Brooke, because he lacked political ambition and also because the negara of Bali did not offer the opportunity.

In the end, Mads Lange's position was the same as when he arrived in Kuta in 1839: that of a sympathetic loser. 